\title{
Description of Merluccius tasmanicus sp. nov. and redescription of Merluccius australis (Pisces: Merlucciidae)
}

\author{
J. Matallanas $*^{\ddagger}$ and D. Lloris ${ }^{\dagger}$ \\ *Unidad de Zoología, Departamento de Biología Animal, Biología Vegetal y Ecología. Universidad Autónoma de Barcelona, 08193 , \\ Bellaterra, Barcelona, Spain. 'Institut de Ciències del Mar (CMIMA-CSIC), Passeig Marítim de la Barceloneta 37-49, \\ 08003 Barcelona, Spain. E-mail: lloris@icm.csic.es. ${ }^{\ddagger}$ Corresponding author, e-mail: jesus.matallanas@uab.es
}

\begin{abstract}
A new hake species, Merluccius tasmanicus sp. nov., is described from New Zealand waters and another species, Merluccius australis is redescribed. Merluccius tasmanicus sp. nov. differs from all other congeneric species in the following combination of characters: upper profile of the head slowly concave; lateral line slowly concave in the caudal region; body depth 4.9-5.9 times in standard length (SL); orbital diameter 6.1-7.1 times in head length, 2.1-2.2 times in snout length and 1.6-1.9 times in interorbital width; second dorsal fin rays, 42-43; anal fin rays, 42-44; lateral line scales $\sim 164$. Merluccius australis is redescribed to clarify the identity of this species. Merluccius australis differs from all other congeneric species in the following combination of characters: upper profile of the head straight; lateral line straight in the caudal region; body depth 6.6-7.1 times in SL; orbital diameter 4.5-5.4 times in head length, 1.2-1.7 times in snout length and 1.0-1.3 times in interorbital width; second dorsal fin rays, 40-43; anal fin rays, 40-43; lateral line scales, more than 155. Merluccius tasmanicus sp. nov. is found in New Zealand and Patagonian waters and occasionally in Japanese waters; Merluccius australis is reported in both New Zealand and Patagonian waters.
\end{abstract}

\section{INTRODUCTION}

Despite its commercial importance, the taxonomic composition of the genus Merluccius is not well known yet. The species of this genus are difficult to distinguish and some of them have been misidentified by authors. Consequently, some taxonomic mistakes still remain.

The most recent reviews of all the species of Merluccius were made by Inada (1981b, 1990). According to Inada (1981b) the genus Merluccius contains 12 distinct species, with two subspecies in both $M$. merluccius and M. gayi, and two distinct geographical populations in $M$. australis. Lloris \& Matallanas (2003) described a new species of hake, M. patagonicus from the Argentine Sea and discussed its relationships with both $M$. hubbsi and $M$. australis. Lloris et al. (2003) recognize 13 species of Merluccius, with three subspecies in $M$. merluccius and with two subspecies in M. albidus, M. polli, M. gayi and M. australis; this latter species being represented by $M$. australis australis off New Zealand waters and by M. australis polylepis from southern South America.

In most parts of the globe two hake species overlap for a considerable part of their geographical ranges. However, in New Zealand waters, only one hake species, Merluccius australis (Hutton, 1872) had been reported as valid until now (Inada, 1981a,b, 1990; Lloris et al., 2003).

The opportunity to examine seven hake specimens off New Zealand waters, all of them catalogued as M. australis (Hutton, 1872), but at a glance pertaining to two groups, confirms our suspicion about the existence of two New Zealand hake species.

A summary of the taxonomic history about the New Zealand and some Patagonian hakes is necessary to introduce this subject. According to the above mentioned authors, the only species of hake living in New Zealand waters is M. australis (Hutton, 1872). This species was described by Hutton (1872) as Gadus australis based on New Zealand specimens with 41 fin rays both in second dorsal and anal fins; Günther (1880) regarded Gadus australis as a synonym of Merluccius gayi (Guichenot, 1848) and assigned to this latter species one specimen (BMNH 1879.5.14.43) with 43-44 second dorsal fin rays and 43 anal fin rays, from the Straits of Magellan; Waite (1911) assigned to $M$. gayi (Guichenot, 1848) one specimen from the Tasman Sea with 36 fin rays both in second dorsal and in anal fins, and included Gadus australis Hutton, 1872 as a synonym of that.

Norman (1937) who studied three South American specimens, 340-345 $\mathrm{mm}$ in total length, but any specimen from New Zealand, says (p. 49): 'I am unable to detect any important differences between the specimen collected by the 'Challenger' in the Messier Channel (Magellan) and those from New Zealand' and identified all of them, including M. gayi Waite, 1911, as Merluccius australis (Hutton, 1872). Consequently, he assigned to this species the range 36-43 fin rays in the second dorsal fin and 36-42 in the anal fin.

Ginsburg (1954), who did not examine either the type specimens of $M$. australis (Hutton, 1872) or any New Zealand specimen of this species, considers that 'the Chilean population evidently differs specifically from that of New Zealand' and based on four specimens from Chiloé (Chile) described M. polylepis.

Inada (1981a) concludes that specimens of M. polylepis from southern South America have similar values for morphometric and meristic characters as those of 
M. australis from New Zealand; consequently, Inada relegated $M$. polylepis to the synonymy of $M$. australis. This author did not examine either the type specimens of $M$. australis or those of $M$. polylepis.

Lloris et al. (2003) consider M. australis is represented by $M$. australis australis off New Zealand waters and by M. australis polylepis from southern South America.

The aim of this paper is to solve the confused identities of some nominal hake species present in both New Zealand and Patagonian waters. As a result of this revision, a new species of hake, Merluccius tasmanicus sp. nov., is described based on four catalogued specimens off New Zealand waters. Besides, M. australis (Hutton, 1872) is redescribed based on the holotype and on three catalogued specimens coming from New Zealand waters. This redescription is necessary to clarify the identity of this species, described vaguely by Hutton (1872), his holotype being a juvenile specimen of $83 \mathrm{~mm}$ SL, and because of misidentifications by later authors. Three subspecies of M. tasmanicus sp. nov. are proposed here.

This taxonomic revision besides its own intrinsic value, can be useful for a rational analysis of hake fisheries in both Patagonian and New Zealand waters. It is generally accepted that proper fishery management requires adequate taxonomic studies to clarify the specific composition of the managed populations.

\section{MATERIALS AND METHODS}

The material examined originates from New Zealand and Patagonian waters. The type series is preserved in the Museum of New Zealand Te Papa Tongarewa (NMNZ), in the Museu Oceanográfico do Vale do Itajaí, Brazil (MOVI), in the National Museum of Natural History, Smithsonian Institution, USA (USNM), and in the Natural History Museum, UK (NHM, formerly BMNH).
The collection numbers are given in the text. Measurements and terminology follow Inada (1981b) and Lloris et al. (2003). All osteological observations were taken from dissected specimens.

Abbreviations: TL, total length; SL, standard length; BD, body depth; HL, head length; IO, interorbital width; PL, pectoral fin length; VL, ventral fin length; D1, first dorsal fin; D2, second dorsal fin; A, anal fin and P, pectoral fin.

\section{RESULTS}

Merluccius tasmanicus sp. nov.

(Figures $1 \&$ 2; Table 1)

Merluccius gayi (not Guichenot, 1848) Waite, 1911, Records of the Canterbury Museum, 1, p. 182, Pl. XXX, figure 2. Merluccius australis (non Hutton, 1872) Norman, 1937, Discovery Reports, 16, 48-49; Inada, 1981a (in part), Fapanese Journal of Ichthyology, 28, 31-36; Inada, 1981b (in part), Bulletin of the Far Seas Fisheries Research Laboratory, 18, 52-56; Inada, 1990 (in part), FAO Fisheries Synopsis, 125, 332-334; Abe \& Funabashi, 1993, Uo, 42, 1-8; Cousseau \& Perrotta, 1998, Peces Marinos de Argentina, 74-75; and Lloris et al., 2003 (in part), FAO Catalogue, 2, 21-23. Merluccius polylepis Ginsburg, 1954 (in part: holotype), Fishery Bulletin, 56, 195-196.

\section{Type material}

Holotype: NMNZ P.5566 (catalogued as M. australis), $374 \mathrm{~mm}$ TL, $343 \mathrm{~mm}$ SL, off Tasman Bay, 40 52'S $173^{\circ} 08^{\prime} \mathrm{E}, 36 \mathrm{~m}$ depth, collected by GRV 'James Cook', 7 January 1972.

Paratypes: three specimens (all catalogued as M. australis), MOVI 27490 and MOVI 27491 (both formerly NMNZ P.1206), 262-269 mm TL, 237-249 mm SL, respectively, off Cape Campbell, $41^{\circ} 44^{\prime} \mathrm{S} 174^{\circ} 16^{\prime} \mathrm{E}$,

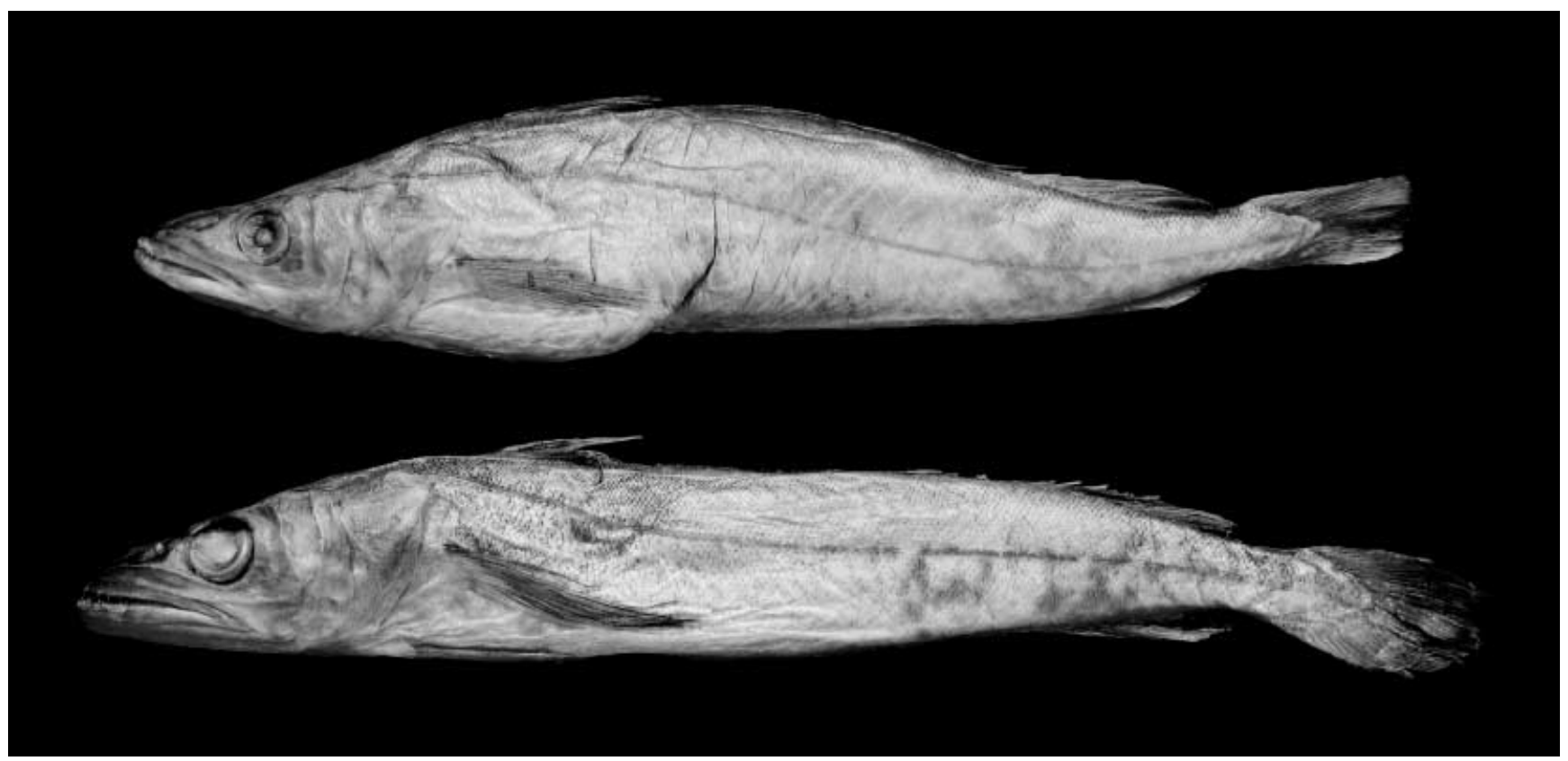

Figure 1. Above: Merluccius tasmanicus sp. nov. Holotype, NMNZ P.5566, $343 \mathrm{~mm}$ SL; Tasman Bay, New Zealand, $40^{\circ} 52^{\prime} \mathrm{S}$ $173^{\circ} 08^{\prime}$ E. Below: M. australis (Hutton, 1873), MOVI 27492, $368 \mathrm{~mm}$ SL; Chalkey Intel, Fiordland, New Zealand, $46^{\circ} 03^{\prime} \mathrm{S}$ $166^{\circ} 20^{\prime} \mathrm{E}$. 


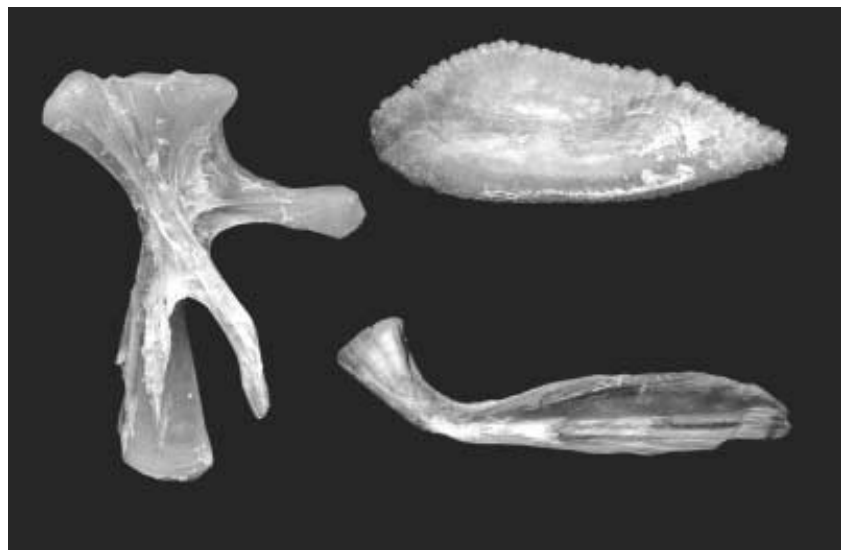

Figure 2. Hyomandybular (left), sagitta (top right) and urohyal (bottom right) of Merluccius tasmanicus sp. nov.

collected byJ. Garrick, 20 November 1952 (MOVI 27491 is partially dissected); and NMNZ P.3963, $404 \mathrm{~mm} \mathrm{TL}$, $370 \mathrm{~mm}$ SL, off Cook Strait, $41^{\circ} 30^{\prime} \mathrm{S} 174^{\circ} 30^{\prime} \mathrm{E}, 91 \mathrm{~m}$ depth, collected March 1964.

\section{Comparative material examined}

Merluccius polylepis Ginsburg, 1954. Holotype (USNM 157764) (Castro, Chile; after $42^{\circ} 29^{\prime} \mathrm{S}$ Merluccius gayi Günther, 1880 (not Guichenot, 1848), after (BMNH 1879.5.14.43); Expedition: HMS 'Challenger' (Gray Harbour, Messier Channel, Straits of Magellan); also the specimens examined for the redescription of $M$. australis, see below for this species.

\section{Diagnosis}

Merluccius tasmanicus sp. nov. differs from all other congeneric species in the following combination of characters (in parentheses data from the holotype): body stout; body depth 5.4-6.5 (5.7) times in TL and 4.9-5.9 (5.3) times in SL; dorsal profile of the head slowly concave, rising to the occiput; orbital diameter 6.1-7.1 (6.1) times in head length, 2.1-2.2 (2.1) in snout length and 1.6-1.9 (1.6) times in interorbital width; lateral line gently bowed over the pectoral fin; in the caudal region it is slowly concave; first dorsal fin rays, 10-12; second dorsal fin rays, 42-43 (42); anal fin rays, 42-44 (44); pectoral fin rays, $13-15 ; \sim 164$ lateral line scales in the holotype; first gill arch with $2-3+9-11(2-3+9)$ gill rakers.

\section{Description}

Body robust and relatively short; its depth nearly six times in SL in smaller specimens but less of this in longer ones; head pike-like and rising to the occiput with its dorsal profile more concave in adult specimens than in juveniles; eye very small, its upper border not reaching the dorsal profile of the head; orbital diameter half the snout length or less; mouth oblique and jaws relatively slender, maxillary reaching hinder edge of pupil; lower jaw very slightly projecting beyond upper jaw. Nasal membrane, lacrimal and lower part of both preopercle and interopercle scaleless; lower part of the cheek with scales. Pectoral extending nearly to third or fourth anal fin rays in specimens smaller than $250 \mathrm{~mm}$ SL, in longer ones it does not reach the anal fin origin; upper pectoral fin ray inserted at level of ventral edge of eye. Posterior margin of the caudal fin, truncate. Lateral line extremely pronounced, gently bowed over the pectoral and, in the caudal region, nearer to ventral profile than to the dorsal one, and slowly concave. Morphometry: body depth 5.4-6.5 (5.7) in TL and 4.9-5.9 (5.2) in SL; head length 3.8-3.9 (3.8) in TL and 3.5-3.6 (3.5) in SL; orbital diameter 6.1-7.1 (6.1) in HL; snout 2.8-3.2 (2.9) in HL; interorbital width $3.4-3.6$ (3.5) in HL; pectoral fin length 1.5-1.9 (1.5) in HL; ventral fin length 2.1-2.4 (2.3) in HL; orbital diameter 2.1-2.2 (2.1) in snout and 1.6-1.9 (1.6) in interorbital width; ventral fin length, 1.2-1.5 (1.2) in pectoral fin length. Colour: preserved specimens present brownish colour, darker on the dorsal side; greyish mouth cavity and tongue; black under opercles; fresh specimens are purplish-brown above, silvery in ventral side, dark grey inside the mouth and in the caudal rays.

\section{Etymology}

Named after the bay from which the holotype originates (Tasman Bay).

\section{Distribution}

New Zealand and Patagonian, and Chilean and Argentine waters. One specimen of this species was captured in Japanese waters (Abe \& Funabashi, 1993). Based mainly in the geographical distance between the populations from which the examined specimens originate, as well as on some morphometric and meristic differences observed, the most appropiate thing would be to assign a subspecific status to each of these populations. Some anatomical differences observed between the New Zealand and Patagonian specimens will be explained in a future paper when more specimens for dissections are available to us.

\section{Redescription of Merluccius australis (Hutton, 1872)}

(Figure 1, Table 1)

Gadus australis Hutton, 1872, Fishes of New Zealand, pp. 45, pl. vii, figure 72; M. gayi (not Guichenot, 1848) Günther, 1880, Shore Fishes, Challenger Report I, 6, 22; M. polylepis Ginsburg, 1954 (in part: holotype USNM 157764), Fisheries Bulletin, 96(56), 197-196 and tables. Inada, 1981a (in part), Fapanese Fournal of Ichthyology, 28, 31-36; Inada, 1981b (in part), Bulletin of the Far Seas Fisheries Research Laboratory, 18, 52-56; Inada, 1990 (in part), FAO Fisheries, Synopsis, 125, 332-334; Lloris et al., 2003 (in part), FAO Catalogue, 2, 21-23.

\section{Material examined}

Merluccius australis (Hutton, 1872). Holotype (BMNH 1905.11.30.38), Cook Strait, New Zealand. Two specimens of Merluccius australis (MOVI 27492-27493, formerly NMNZ P.13122) (Chalkey Intel, Fiordland, New Zealand; $46^{\circ} 03^{\prime} \mathrm{S} 166^{\circ} 20^{\prime} \mathrm{E}$ ), collected 23 October 1982, $370 \mathrm{~m}$ depth. One specimen (NMNZ P. 13122) (Chalkey Intel, Fiordland $)\left(46^{\circ} 03^{\prime} \mathrm{S} \quad 166^{\circ} 20^{\prime} \mathrm{E}, 370 \mathrm{~m}\right.$ depth $)$, collected 23 October 1982, $370 \mathrm{~m}$ depth.

\section{Comparative material examined}

Merluccius gayi Günther, 1880 (not Guichenot, 1848) (BMNH 1879.5.14.43); Expedition: HMS 'Challenger' (Gray Harbour, Messier Channel, Straits of Magellan). 
196 J. Matallanas and D. Lloris Nerw species of Merluccius (Pisces: Merlucciidae)

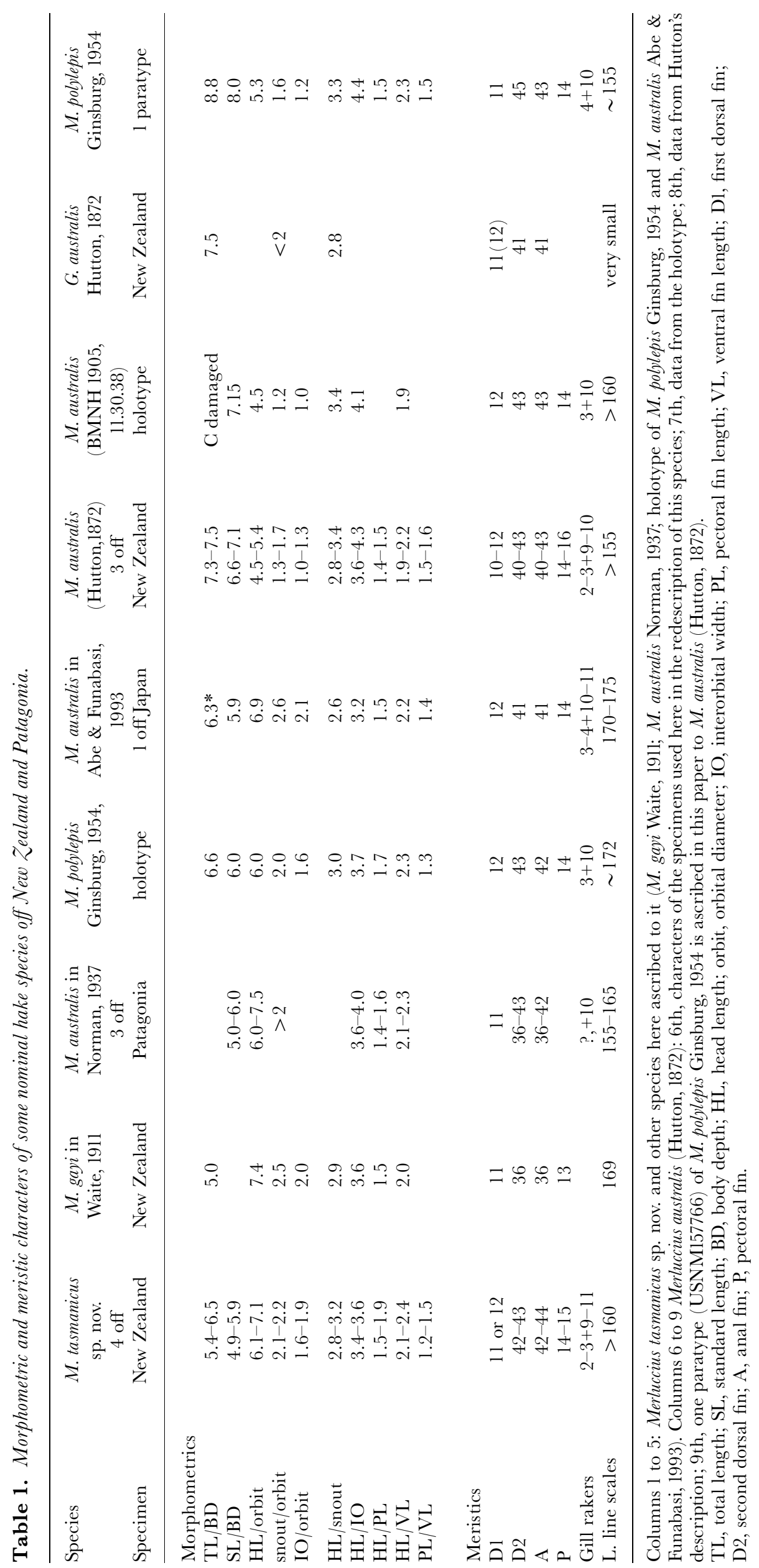


Merluccius polylepis Ginsburg, 1954. Paratype (USNM 157766) (Castro, Chile; $43^{\circ} 01^{\prime} 30^{\prime \prime} \mathrm{S} 72^{\circ} 50^{\prime} \mathrm{W}$ ), collected 20 January 1945. Two uncatalogued specimens of Merluccius australis off Chilean waters $\left(46^{\circ} 22^{\prime} \mathrm{S} 75^{\circ} 27^{\prime} \mathrm{W}\right)$ used for anatomical studies. Also the specimens used for the description of Merluccius tasmanicus sp. nov.: see below for this species.

\section{Remarks}

The redescription of $M$. australis is necessary to clarify the identity of this species, described vaguely by Hutton (1872) and because of misidentifications by later authors. This redescription is based on Hutton's (1872) original description of Gadus australis as well as in the study of the holotype of this species, a juvenile specimen of $83 \mathrm{~mm}$ SL, and also on three catalogued specimens, 404, 418 and $443 \mathrm{~mm}$ SL, off New Zealand waters.

The diagnostic characters given by Hutton (1872) in the original description of this species are as follows: 'length equal to seven and a half times the height of the body'; 'diameter of the eye not much more than half the length of the snout'; 'upper profile of the head straight'; 'lower jaw longer; strong teeth in both jaws'; 'scales very small'; 'D2: 41; A: 41'.

\section{Redescription}

(Data from Hutton's description or from the holotype of $M$. australis are in parentheses.) Body slender; body depth 7.3-7.5 (7.5) times in TL and 6.6-7.1 (7.1) times in SL; orbital diameter 4.5-5.4 (4.5) times in head length (HL), 1.2-1.7 (1.2) times in snout length and 1.0-1.3 (1.0) times in the interorbital width. Other non-diagnostic morphometric characters are as follows: head length 3.9-4.3 (4.3) times in TL and 3.3-3.6 (3.4) in SL; snout length 2.8-3.4 (3.4) times in HL; interorbital width 3.6-4.3 (4.1) times in HL; pectoral fin length 1.4-1.5 (-) times in HL; ventral fin length 1.9-2.3 (1.9) times in HL; ventral fin length 1.5$1.6(-)$ times in pectoral fin length.

Body relatively long; upper profile of the head straight; eye large: orbit more than half snout length; upper edge of the eye reaching the dorsal profile of the head; strong jaws: maxillary reaching the hinder border of pupil in the juvenile $83 \mathrm{~mm}$ SL holotype, but reaching the posterior edge of the eye in the remaining ones; lower jaw longer than upper. Nasal membrane, lacrimal and lower part of both preopercle and interopercle without scales; lower part of the cheek with scales. Pectoral fin damaged in the holotype, in the other examined specimens, including those longer than $40 \mathrm{~cm} \mathrm{TL}$, it extends beyond anal fin origin; ventral fin nearly reaching the vent in the holotype, while in the others it reaches only two-thirds of the distance from its origin to vent; upper pectoral fin ray inserted at level of the middle of eye; posterior margin of caudal fin nearly rounded. The lateral line descends slowly from its origin to the middle of the body, being then straight and at the same distance from dorsal and ventral profiles.

First dorsal fin rays, 10-12 (12); second dorsal fin rays, 40-43 (43); anal fin rays, 40-43 (43); pectoral fin rays, 14-16 (14); first gill arch with $2-3+9-11(3+10)$ gill rakers; lateral line damaged in the holotype; $\sim 155-160$ lateral line scales in the other New Zealand specimens examined.
Colour: Hutton (1872) says 'above purplish, sides and belly silvery, inside of the mouth white'. Adult preserved specimens are dark grey on back and lighter on sides and belly; dorsal fins, caudal and pectoral fins blackish; mouth cavity, tongue and subopercular membrane black.

\section{Subspecies}

Lloris et al. (2003) recognized two subspecies: Merluccius australis australis for the population of New Zealand waters and Merluccius australis polylepis for that of the Patagonian waters, both Chilean and Argentine. The main meristic characters of the specimens of each subspecies studied for this paper are as follows:

\section{Merluccius australis australis (New Zealand waters)}

D1, 10-12; D2, 40-43; A, 40-43; P, 14-16; gill rakers, 2-3+9-11; lateral line scales, $\sim 155-160$.

Merluccius australis polylepis (Chilean and Argentine waters)

D1, 10-13; D2, 42-45; A, 42-43; P, 12-16; gill rakers, 2-4+9-11; lateral line scales, 155-174.

\section{DISCUSSION}

Merluccius tasmanicus sp. nov. and M. australis (Hutton, 1872) agree in having many oblique rows of scales, and in the distribution of the head scales. However, M. tasmanicus sp. nov. differs from M. australis (Hutton, 1872) in some non-overlapping morphometric characters (data of $M$. australis in parentheses): body depth 5.4-6.5 times in TL (vs 7.3-7.5) and 4.9-5.9 in SL (vs 6.6-7.1); orbital diameter 6.1-7.1 times in head length (vs 4.5-5.4), 2.1-2.2 times in snout length (vs $1.2-1.7$ ) and $1.6-1.9$ times in interorbital width (vs 1.0-1.3). Other distinctive characters are as follows (those of $M$. australis in parentheses): lateral line bowed over the pectoral fin (vs descending); lateral line slowly concave in the caudal region (vs straight); upper profile of the head slowly concave (vs straight); eye distant from the dorsal profile of the head (vs reaching it); pectoral fin end not reaching the anal fin origin in specimens of $M$. tasmanicus sp. nov. longer than $40 \mathrm{~cm}$ TL (extending beyond it in similar size ones of M. australis).

The comparison of the original description of M. australis (Hutton, 1872) as from the holotype of this species, and the original description and figure of $M$. gayi made by Waite (1911), both based on specimens from New Zealand waters, confirms that they are different species (Table 1). Some characters can corroborate this (data from Waite in parentheses): body depth 7.5 times in TL (vs 5.0); orbital diameter 4.5 times in head length (vs 7.4), 1.2 times in snout length (vs 2.5) and 1.0 times in interorbital width (vs 2.0). Furthermore, Hutton's hake has the lower jaw longer than the Waite's one and the lateral line shape is also different in the two hakes. So, there is no doubt that M. gayi Waite, 1911 cannot be a synonym of M. australis (Hutton, 1872).

Merluccius gayi Waite, 1911 is not M. gayi (Guichenot 1848). Some comparative data from both species support this opinion (data from Waite's hake in parentheses): lateral line scales, 106-144 (vs 169); orbital diameter 4.5-5.9 times in head length (vs 7.4); pectoral 
fin extending beyond anal fin origin (vs to vent); caudal fin concave (vs truncate), and many others. Both morphometric and meristic characters and others as body and lateral line shape of the Waite's specimens fit into the description of $M$. tasmanicus sp. nov. Waite's counts of 36 rays for both second dorsal and anal fins is very low, and probably erroneous, compared with our counts on New Zealand specimens of $M$. tasmanicus sp. nov. Probably, Waite did not count the posterior dorsal and anal fin rays which are very slender and difficult to observe.

The morphometric and meristic characters of the specimen from Gray Harbour, Straits of Magellan (BMNH 1879.5.14.43) assigned by Günther (1880) to M. gayi (Guichenot, 1848) agree with those of $M$. australis (Hutton, 1872).

The specimens of the Straits of Magellan erroneously assigned by Norman (1937) to M. australis (Hutton, 1872), belong to M. tasmanicus sp. nov. The diagnostic morphometric characters given by this author (body depth 5 to 6 in length; snout more than twice as long as the eye; eye diameter 6 to 7.5 in head length) disagree with those of the species described by Hutton and agree with those of the new species here described (Table 1).

The Ginsburg (1954) description of M. polylepis is based on specimens of two species: one paratype (USNM 157766) belongs to M. australis (Hutton, 1872), the holotype to $M$. tasmanicus sp. nov. (Table 1 ).

The characters and figure assigned by Cousseau \& Perrotta (1998) to $M$. australis off the Argentine Sea, page 74 and figures on the same page, belong to M. tasmanicus sp. nov.

As it has been pointed out above, M. tasmanicus sp. nov. and $M$. australis (Hutton, 1872) can be easily separated by some morphometric non-overlapping characters. Some of them are the relation between standard length/body depth and the relation between each, head length, snout and interorbital width with the orbital diameter, which are species specific.

The wide range of some morphometric characters assigned to $M$. australis (Hutton, 1872) namely a body depth 4.9-7.2 times in SL and an orbital diameter 4.5-7.2 times in head length, by Inada (1981b, 1990) can be explained accepting that they are based on specimens of both M. tasmanicus sp. nov. and M. australis (Hutton, 1872).

The characters assigned by Lloris et al. (2003) to M. australis (Hutton, 1872) are inaccurate; they included those coming from New Zealand and Patagonian specimens of this species studied by the authors, but also some other mistakenly assigned to this species by previous authors. The picture assigned to $M$. australis (figure 1, upper right, p. 325) by Lloris \& Matallanas (2003) is not from a specimen of that species but from a specimen of M. tasmanicus sp. nov.

At present, M. australis and M. tasmanicus sp. nov. are the only hake species reported in New Zealand waters. However, in Argentine waters two more hake species are reported: M. hubbsi Marini, 1933 and M. patagonicus Lloris \& Matallanas, 2003. Merluccius australis and M. tasmanicus sp. nov. differ from both $M$. hubbsi and $M$. patagonicus in many characters, and among others in having more lateral line scales (155-174 vs 123-144), more second dorsal fin rays (40-45 vs 36-40) and anal fin rays (40-45 vs $36-40)$.
Biogeographically speaking both $M$. australis and M. tasmanicus sp. nov. are presumably associated with the Weddellian zoogeographical province. This was, according to Zinsmeister (1982) a late Cretaceous-early Tertiary temperate shallow region extending from Patagonia, along the Antarctic Peninsula and West Antarctic to New Zealand and south-eastern Australia. The disjoint area occupied now by each subspecies of both $M$. australis and $M$. tasmanicus can be a result of the vicariant event that fragmented this province, mainly the formation of the circumantarctic current, which was established in the late Oligocene (Kennett, 1980). The presence of one specimen of $M$. tasmanicus sp. nov. in Japanese waters is, however, intriguing.

The report of $M$. australis off the epipelagial zone northeast of the South Shetland Islands $\left(59^{\circ} 59^{\prime} \mathrm{S} 52^{\circ} 39^{\prime} \mathrm{W}\right)$ (Trunov, 1999) cannot be corroborated because no specimens are preserved to confirm it. Besides, the presence of one species of Merluccius in the Southern Ocean cannot be confirmed yet because the three specimens classified as M. polylepis (BMNH 1979.7.11.55-57) coming from the Weddell Sea are missing.

Because of its commercial importance a brief comment about hake fisheries is probably adequate. Today the genus Merluccius is one of the most heavily fished demersal groups; almost two million tonnes of hake are caught annually (Pitcher \& Alheit, 1995). In most parts of the globe two hake species overlap a considerable part of their geographical ranges, and these pairs of species have often been lumped together in the commercial catch data. The captures of the New Zealand hake (M. australis), which according to Colman (1995) is taken as by-catch in the trawl fisheries targeting on hoki (Macruronus novaezelandiae), include not only those of $M$. australis as it was believed but also those of the M. tasmanicus sp. nov. In Argentina there is a hake targeted fishery; hake catches represented 63\% of the total catch of the Argentine fleet (Bezzi et al., 1995). Despite its pre-eminence in the Argentine fishing industry, in the commercial catch data no distinction has been made between the species. Merluccius australis has been considered only of minor importance in the Argentine hake fishery as a whole, and the current management strategy only considers $M$. hubbsi. A large amount of information on M. hubbsi and M. australis overlaps (Csirke, 1987; Lloris et al., 2003). Moreover the identity of $M$. australis (Hutton, 1872) has been mistaken by authors, as mentioned above, and a large amount of specimens assigned to that species belong to $M$. tasmanicus sp. nov. It is also very likely that specimens of $M$. patagonicus have been mistakenly assigned to $M$. hubbsi (Lloris \& Matallanas, 2003).

At present, after the description of $M$. patagonicus (Lloris \& Matallanas, 2003), that of M. tasmanicus sp. nov. and the redescription of $M$. australis, in this paper, the taxonomic panorama of the New Zealand and Patagonian hakes is more intelligible. However, a global study of these hake fisheries, mainly in the south-west Atlantic, where there is a fishery targeted on hake should be undertaken to clarify the biology and the fishery management of these four hake species.

Accuracy on species identification and linkage to specimens deposited in museums are the key to ensuring credibility of biological as well as political considerations 
concerning fisheries. As Rosen (1986) pointed out, reliable taxonomy is the basis for all meaningful research in biology.

We are indebted to many colleagues for the loan or gift of specimens. Jules R. Soto and Michael M. Mincarone (Museu Oceanográfico da Universidade do Vale do Itajaí, Santa Catarina, Brazil) provided New Zealand specimens for this study. Mr P. Campbell (Natural History Museum, London, United Kingdom) for the loan of the holotype of $M$. australis (BMNH 1905.11.30.38) and other specimens (BMNH 1879.5.14.42-43); Sandra Raredon and Jeff Williams (National Museum of Natural History; Smithsonian Institution, Washington, USA) for the loan of holotype (USNM 157764) and one paratype (USNM 157766) of M. polylepis, as well as a digital photograph and a digital radiograph of that specimen as a gift. G. Pequeño (Instituto de Zoología E. Kilian, Universidad Austral de Chile, Valdivia, Chile) and R. Bravo (Facultad de Ciencias del Mar, Universidad de Valparaiso, Chile) provided us with some uncatalogued specimens of $M$. australis from Chilean waters. S. Meseguer corrected the first English version of the manuscript.

\section{REFERENCES}

Abe, T. \& Funabashi, M., 1993. A record of a Merlucciid fish from Ibaraki Prefecture, Japan. Uo, 42, 1-8.

Bezzi, S.I., Verazay, G.A. \& Dato, C.V., 1995. Biology and fisheries of Argentine hakes (M. hubbsi and M. australis). In Hake. Fisheries, ecology and markets (ed. J. Alheit and T.J. Pitcher), pp. 239-267. London: Chapman \& Hall.

Colman, J.A., 1995. Biology and fisheries of New Zealand hake (M. australis). In Hake. Fisheries, ecology and markets (ed. J. Alheit and T.J. Pitcher), pp. 365-388. London: Chapman \& Hall.

Cousseau, M.B. \& Perrotta, R., 1998. Peces marinos de Argentina. Biología, distribución, pesca. Mar del Plata: Publicaciones Especiales del Instituto Nacional de Investigación y Desarrollo Pesquero (INIDEP), 167 pp.

Csirke, J., 1987. Los recursos pesqueros patagónicos y las pesquerías de altura en el Atlántico sudoccidental. FAO Documento Tecrico de Pesca, 286, 1-78.

Ginsburg, I., 1954. Whitings on the coasts of the American continents. Fishery Bulletin, 96, 187-208.

Günther, A., 1880. Report on the shore fishes procured during the voyage of H.M.S. Challenger during the years 1873-76. Report Scientific Results Exploration Voyage H.M.S. Challenger, Zoology, 1, 1-82; pl. 1-32.
Hutton, F.W., 1872. Fishes of New Zealand. Catalogue with diagnoses of the species. Wellington: James Hunter Printer.

Inada, T., 1981a. Two nominal species of Merluccius from New Zealand and Southern South America. Fapanese Fournal of Ichthyology, 28, 31-36.

Inada, T., 1981b. Studies on the Merlucciid Fishes. Bulletin of the Far Seas Fisheries Research Laboratory, 18, 1-172.

Inada, T., 1990. Merlucciidae. In Gadiform fishes of the world (Order Gadiformes). An annotated and illustrated catalogue of cods, hakes, grenadiers and other gadiform fishes known to date (ed. D.M. Cohen et al.), pp. 327-344. Rome: FAO.

Kennett, J.P., 1980. Paleoceanographic and biogeographic evolution of the Southern Ocean during the Cenozoic, and Cenozoic microfossil datums. Palaeogeography, Palaeoclimatology, Palaeoecology, 31, 123-152.

Lloris, D. \& Matallanas, J., 2003. Description of a new species of hake: Merluccius patagonicus sp. nov. (Gadiformes: Merlucciidae) from the waters of Argentina. Scientia Marina, 67, 323-326.

Lloris, D., Matallanas, J. \& Oliver, P., 2003. Merluzas del Mundo (Familia Merlucciidae). Catálogo comentado e ilustrado de las merluzas conocidas. Rome: FAO Catálogo de Especies para los Fines de la Pesca. No. 2, pp. 57, 11 col. pl.

Norman, J.R., 1937. Coast Fishes. Part II, The Patagonian Region. Discovery Reports, 16, 1-76.

Pitcher, T.J. \& Alheit, J., 1995. What makes a hake?. A review of the critical biological features that sustain global hake fisheries. In Hake. Fisheries, ecology and markets (ed. J. Alheit and T.J. Pitcher), pp. 1-14. London: Chapman \& Hall.

Rosen, D., 1986. The role of taxonomy in effective biological control programs. Agriculture, Ecosystems, Environment, 15, 121-129.

Trunov, I.A., 1999. New data on species of fish from Subantarctic and Antarctic waters of the Atlantic Ocean. Fournal of Ichthyology, 39, 488-497.

Waite, E.R., 1911. Scientific results of the New Zealand Government trawling expedition, 1907. Pisces. Part II. Records of the Canterbury Museum, 1, 157-272, pl. 24-57.

Zinsmeister, W.J., 1982. Late Cretaceous-early Tertiary molluscan biogeography of the southern circum-Pacific. Fournal of Paleontolology, 56, 84-102.

Submitted 14 July 2005. Accepted 4 October 2005. 